Provided for non-commercial research and educational use only. Not for reproduction or distribution or commercial use.

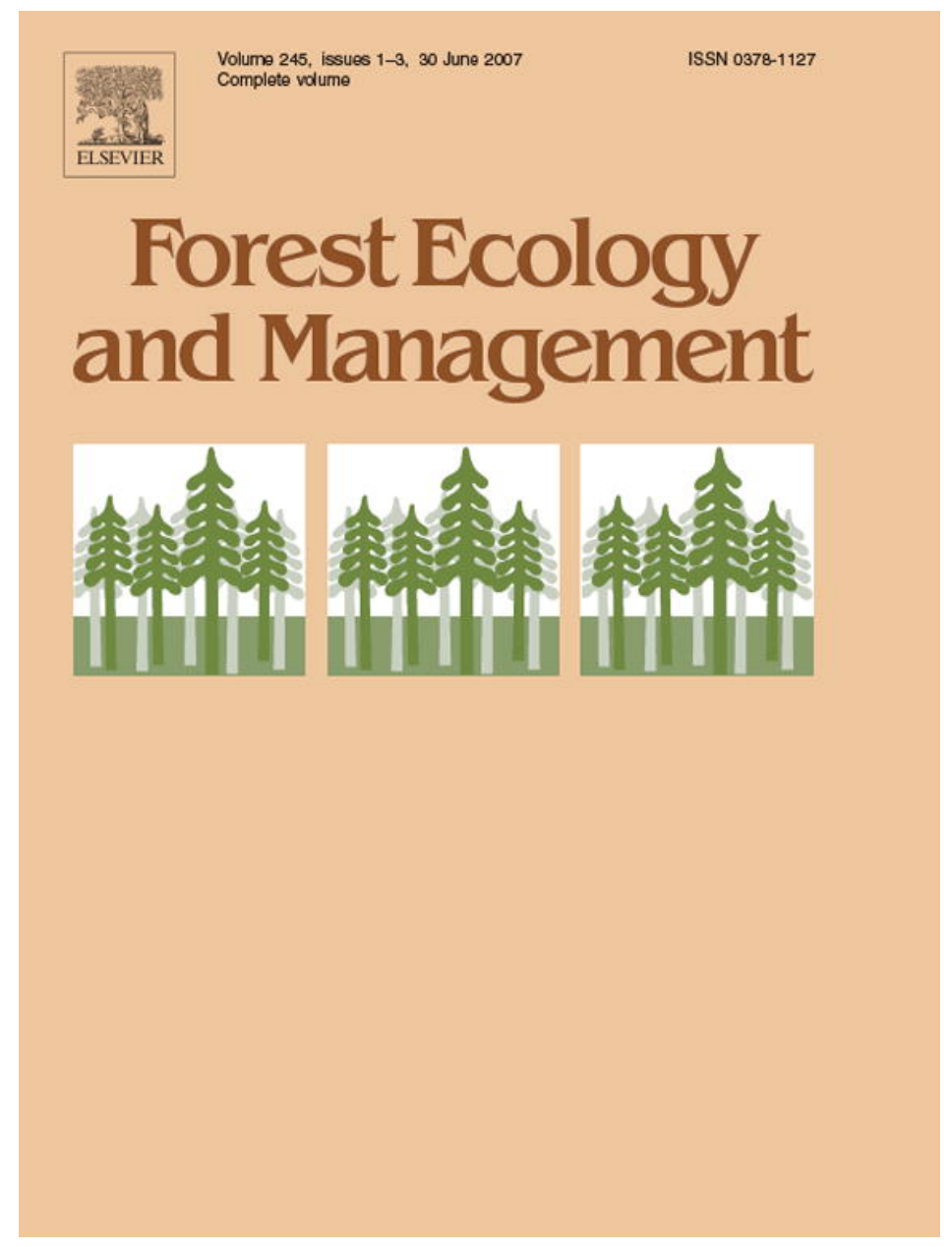

This article was originally published in a journal published by Elsevier, and the attached copy is provided by Elsevier for the author's benefit and for the benefit of the author's institution, for non-commercial research and educational use including without limitation use in instruction at your institution, sending it to specific colleagues that you know, and providing a copy to your institution's administrator.

All other uses, reproduction and distribution, including without limitation commercial reprints, selling or licensing copies or access,

or posting on open internet sites, your personal or institution's website or repository, are prohibited. For exceptions, permission may be sought for such use through Elsevier's permissions site at: 


\title{
Effects of selective logging on the abundance, regeneration and short-term survival of Caryocar costaricense (Caryocaceae) and Peltogyne purpurea (Caesalpinaceae), two endemic timber species of southern Central America
}

\author{
Jorge Lobo $^{\text {a,* }}$, Gilbert Barrantes ${ }^{\text {a }}$, Marvin Castillo ${ }^{\text {b }}$, Ruperto Quesada ${ }^{\text {b }}$, \\ Tirso Maldonado, Eric J. Fuchs ${ }^{\mathrm{c}}$, Silvia Solís ${ }^{\mathrm{d}}$, Mauricio Quesada ${ }^{\mathrm{d}}$ \\ ${ }^{a}$ Universidad de Costa Rica, Escuela de Biología, San Pedro, Costa Rica \\ ${ }^{\mathrm{b}}$ Instituto Tecnológico de Costa Rica, Escuela de Ingeniería Forestal, Cartago, Costa Rica \\ ${ }^{\mathrm{c}}$ Department of Plant Biology, The University of Georgia, Athens, GA 30602-7271, United States \\ ${ }^{\mathrm{d}}$ Centro de Investigaciones en Ecosistemas, Universidad Nacional Autónoma de México, Campus Morelia, \\ Apartado Postal 27-3 (Xangari), Morelia, Michoacán, México 58089, Mexico \\ Received 25 August 2006; received in revised form 29 March 2007; accepted 31 March 2007
}

\begin{abstract}
In this study, we determined the effects of selective logging on the abundance of the last remnant populations of two tropical timber species with a restricted distribution, Caryocar costaricense and Peltogyne purpurea. We conducted a census of adult tree densities for these species on 94 selectively logged sites located in a tropical rain forest on the Osa Peninsula, Costa Rica. We compared the abundance of juveniles and seedlings for both tree species on 11 logged and unlogged sites. In addition, we analyzed the growth and mortality rates of adult trees of $P$. purpurea $(>10 \mathrm{~cm}$ $\mathrm{dbh}$ ) in a 4 ha permanent plot that was selectively logged once in 1992. Both species presented a heterogeneous density distribution over the Osa Peninsula (166,668 ha) and the highest density of both species is located in the region of the highest logging activity. For $C$. costaricense, seedling (height $<50 \mathrm{~cm}$ ) and juvenile (height $>50 \mathrm{~cm}, \mathrm{dbh}<2 \mathrm{~cm}$ ) abundance was greater in unlogged areas, while trees $2-10 \mathrm{~cm}$ dbh were more abundant in logged areas. For P. purpurea, seedlings were more abundant in unlogged areas, but small and large juvenile abundance did not differ between selectively logged treatments. The density of $P$. purpurea adult trees remained constant 15 years after selective logging but the density of trees 10-30 cm dbh decreased in the same period. We predict that recurrent 15 year cutting cycles of $50 \%$ of timber trees with restricted distribution, as it is practiced by conventional logging in Costa Rica, may lead a significant reduction of the main reproductive individuals, decreasing the regeneration of the populations subjected to exploitation and fragmentation.
\end{abstract}

(C) 2007 Elsevier B.V. All rights reserved.

Keywords: Selective logging; Tropical forests; Plant demography; Rare species; Plant biogeography

\section{Introduction}

Selective logging has been denoted as the practice of harvesting the most important timber species in natural forests, allowing the remaining forest to naturally regenerate over time (Bawa and Seidler, 1998). The term selective logging has been used to describe different forest management techniques that range from large-scale mechanized tree extraction over large

\footnotetext{
* Corresponding author. Tel.: +506 2075958; fax: +506 2074216 .

E-mail address: jorgelobosegura@gmail.com (J. Lobo).
}

tracts of forest to local small-scale extraction using animal traction (Bawa and Seidler, 1998; Asner et al., 2005). Selective logging has been proposed as a possible strategy for timber extraction from tropical rain forests without the destructive nature of clear-cutting techniques (World Resources Institute, 1985). Nonetheless, because of the heavy machinery and techniques used by large-scale selective logging, its impact could be important in terms of biodiversity loss, commercial extinction of species, and vegetation and soil physical damage (Nepstad et al., 1999; Asner et al., 2005; Dauber et al., 2005). There is evidence that selective logging can damage the remaining trees in natural forests, compact soils and can alter 
potential habitats for regeneration (Uhl and Guimarães-Vieira, 1989). Regardless of the extraction technique, two main variables in selective logging include the proportion of adult trees extracted per species per area, and the frequency of extraction over time (i.e. cutting cycles). The regeneration of timber species after logging has been evaluated at the community level on the germination, survival and growth rate of juvenile and adult stages in logging gaps (Cannon et al., 1998; Costa and Magnusson, 2003). However, few studies have followed the demographic dynamics of timber species in remnant populations after logging (Guariguata and Sáenz, 2001). In addition, other aspects rarely considered in studies that evaluate the impact of selective logging include the degree of endemism of exploited species, fragmentation of remnant populations and the existence of genetic reservoirs other than the exploited populations.

Selective logging is a timber harvesting practice implemented in several tropical countries and it has been proposed as a successful alternative method for the sustainable exploitation of these complex natural communities (Bawa and Seidler, 1998). An example is Costa Rica, where a national forestry law allows selective logging of natural forests and receive a special payment for environmental services through the government. According to this law, private landowners are compensated for the environmental services provided by the management of natural forests. An analysis of this policy states that this program is designed to stimulate the exploitation of natural forests outside protected areas by investing the funds obtained for conservation in economic incentives for deforestation (Quesada and Stoner, 2004). This type of management typically eliminates about $50 \%$ of commercially viable trees with densities above 0.3 individuals $\mathrm{ha}^{-1}$. The number of extracted trees varies greatly with the density of commercially important timber species, which is dependent upon the botanical composition of the forest, current value of timber and the methods of exploitation. In Costa Rica, between the years 1997 and 2001, a total of 116,250 trees were extracted under management plans (Varela, personal communication). In southern Costa Rica, many of the commercial timber species are endemic or restricted to southern Central America, and southwestern Colombia (Quesada et al., 1997). The forest cover in these regions had been dramatically reduced in the last 50 years (Maldonado, 1998), and the commercial exploitation of these species may threaten their demographic and reproductive future. Osa Peninsula in southwestern Costa Rica is one of the few remnants of rain forest along the Pacific slope of Mesoamerica and many of the tree species found in this region belong to northern South American taxonomic groups (Quesada et al., 1997). The timber species evaluated in this study, Caryocar costaricense Donn. Sm. and Peltogyne purpurea Pittier, are part of this taxonomic group. On the Osa Peninsula, the logging activity on these species has been focused on the largest individuals within local populations (Barrantes et al., 1999). Therefore, the study of the logging impact on these species provides important information for the conservation and maintenance of the logged species of southern Central America.
The objectives of this study are: (1) to determine the abundance of one of the last remnant populations of two important timber species currently used for selective logging along their geographical range, $C$. costaricense and $P$. purpurea in Osa Peninsula, Costa Rica, (2) to determine the effects of selective logging on seedling and sapling abundance for these two species 4-5 years after timber extraction, (3) to reveal short-term (15 years) population growth and demographic structure of the adult stage of a managed population of $P$. purpurea.

\section{Methods}

\subsection{Study site}

This study was conducted in a tropical rain forest at Golfo Dulce Forestry Reserve (61,702 ha), Osa Peninsula, southwestern Costa Rica $\left(8^{\circ} 25^{\prime}-8^{\circ} 50^{\prime} \mathrm{N}, 83^{\circ} 15^{\prime}-83^{\circ} 45^{\prime} \mathrm{W}\right)$ which is connected by a natural corridor with Corcovado National Park $(42,469$ ha). The Golfo Dulce Forestry Reserve is a group of properties privately owned by approximately 450 peasant landholders; land use within each property is regulated by the Costa Rican Government (Claudine et al., 2003). The size of each property ranges from 5 to 400 ha. Although Golfo Dulce Forestry Reserve was created under a Government Decree in 1978, during the years 1980-1995, deforestation within the Reserve was approximately 1000 ha year $^{-1}$ and more than $65,000 \mathrm{~m}^{3}$ of timber were extracted during 1996-1999 (Barrantes et al., 1999; Rosero-Bixby et al., 2002). Osa Peninsula has an extension of approximately 166,668 ha, where 108,049 ha were mature forest in 1995. Average annual rainfall ranges from 3500 to $5000 \mathrm{~mm}$ and the mean temperature is $27{ }^{\circ}$ C. Soils at Osa Peninsula are predominantly ultisols with few areas of entisols on the north side of the Reserve (Weissenhofer and Huber, 2001). Seventy percent of the topography at Osa Peninsula is dominated by steep slopes with a maximum altitude of $782 \mathrm{~m}, 23 \%$ of moderate slopes and $7 \%$ of lowland plains near the ocean.

\subsection{Study species}

C. costaricense Donn. Sm. (Caryocaceae) is a Neotropical emergent tree with a distribution restricted to Costa Rica and Panama (Prance, 1976). In Costa Rica, C. costaricense is found in very moist forests along the Pacific coast from Herradura, Nicoya Gulf, to Osa Peninsula; the latter being the most important refuge of this species throughout its distribution (Quesada et al., 1997; IUCN, 2006). C. costaricense is generally found in well-drained hills and mountains with slopes between 15 and 30\% (Jiménez, 1999). Flowering occurs between January and February and flowers are believed to be bat pollinated. The fruits are drupes with one seed averaging $4 \mathrm{~cm}$ diameter average size. Fruiting occurs between March and May, there is no information regarding seed dispersal.

$P$. purpurea Pittier (Caesalpinaceae) is a Neotropical timber tree, endemic to Costa Rica and Panama. In Costa Rica, $P$. purpurea is mainly found in the south pacific coast between 
Carara National Park and the Osa Peninsula, the latter being the location with the highest density of this species (Jiménez, 1993). This species grows in well-drained hills and slopes with steepness between 40 and $80 \%$. Flowering occurs between August and December, and fruiting is restricted to the driest months of the year (Quesada et al., 1997). Fruits are single seeded wind-dispersed, dehiscent legumes which explode when dry. $P$. purpurea grows in red clay soils impoverished by weathering (Weissenhofer and Huber, 2001).

\subsection{Current legal practices of selective logging in Costa Rica}

Commercial logging in Costa Rica is accomplished within the legal framework of "Forestry Management Plans" (Forestry Law 7575). There are three major components to develop a management plan. First, a forestry inventory of all trees $(>10 \mathrm{~cm} \mathrm{dbh})$ within the managed property is conducted, commonly using 10,100-m $\times 30$-m plots. Local densities are estimated with the forestry inventory data. Second, the establishment of an area for absolute protection that includes sections of the property $50 \mathrm{~m}$ away from rivers and streams, and slopes over $30 \%$. Third, selection of trees for commercial extraction outside of the area dedicated for absolute protection; the selection includes $50 \%$ of the individuals with $>50 \mathrm{~cm} \mathrm{dbh}$, pertaining to species with local densities greater than 0.3 individuals $\mathrm{ha}^{-1}$. A cutting cycle of 15 years is established in most of the management plans. Between 1997 and 1999, 165 forestry management plans were officially approved by the Government of Costa Rica in the Osa Peninsula, allowing legal extraction of 14,346 trees with a total volume of $65,000 \mathrm{~m}^{3}$.

\subsection{Analysis to estimate natural abundance and density of C. costaricense and P. purpurea}

Regional densities of $C$. costaricense and $P$. purpurea throughout the Osa Peninsula were estimated using the forestry inventories of 94 selected forest management plans that were conducted during years 1997-2001. The selection of forest management plans was based upon the taxonomic accuracy of species identification, the information related to the $\mathrm{dbh}$, and the geographic coverage that most likely match our study species range within Osa Peninsula. We included as much variation possible in a topographic and altitudinal gradient within the Peninsula to assure the widest coverage of environmental variables that might be related to density and abundance of our study species. This in turn, provided more power of predictability to the kriging interpolation method (Surfer ${ }^{\circledR}$, Golden Software, Inc. 2002) used to estimate the density of each tree species throughout Osa Peninsula (see below) (Fig. 1). Forestry inventories were conducted on 5-20ha areas, and the density of each tree species were estimated for individuals $>50 \mathrm{~cm} \mathrm{dbh}$. The location of the 94 forest managed areas and the three permanent plots within Corcovado National

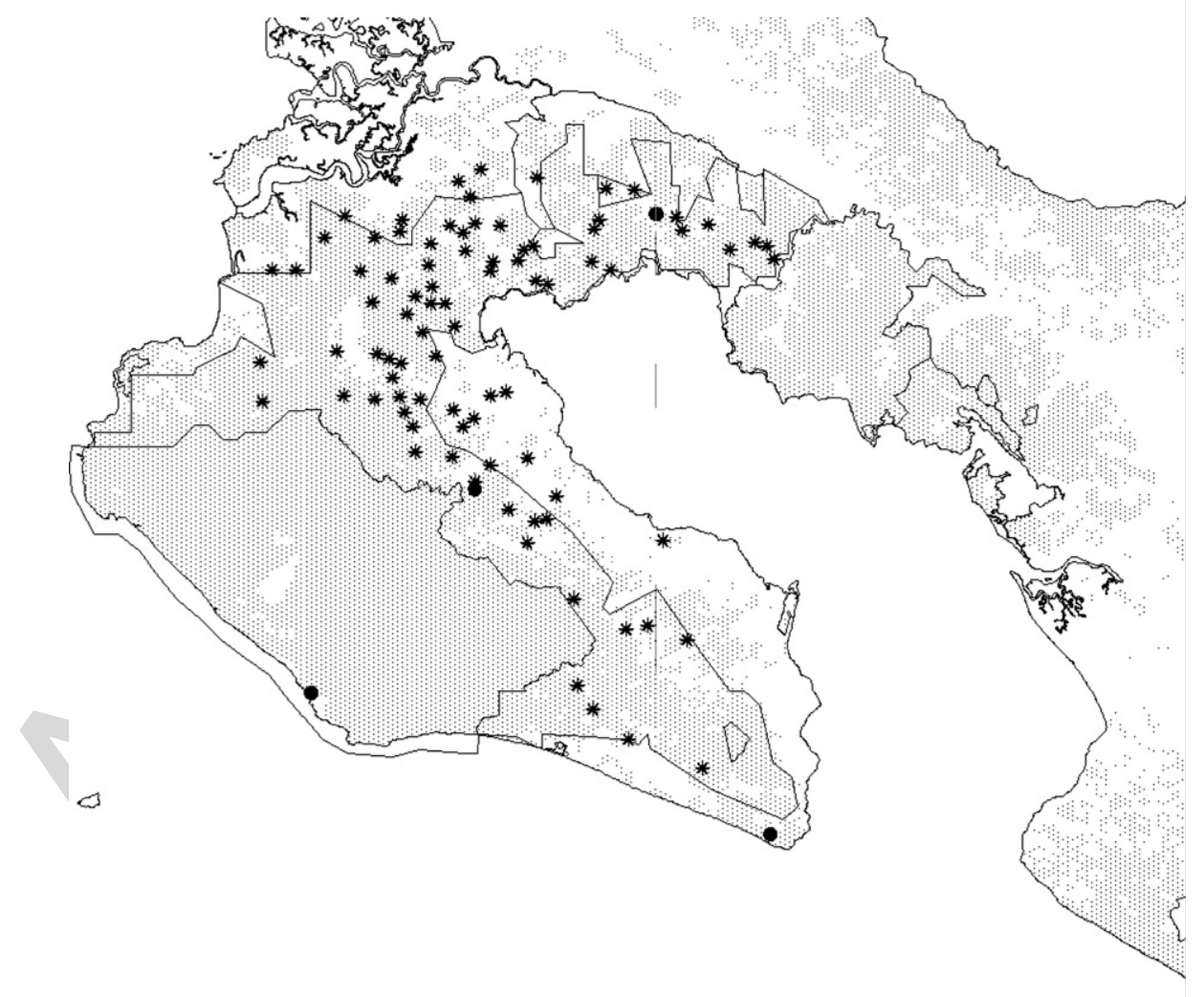

Fig. 1. Localization of the 94 farms used to estimate local density of C. costaricense and P. purpurea in Osa Peninsula, Costa Rica. Each asterisk represents a farm with a forest management plan where trees $>50 \mathrm{~cm}$ dbh from both species were counted. Area in gray represents forest cover in 1996 . 
(a)

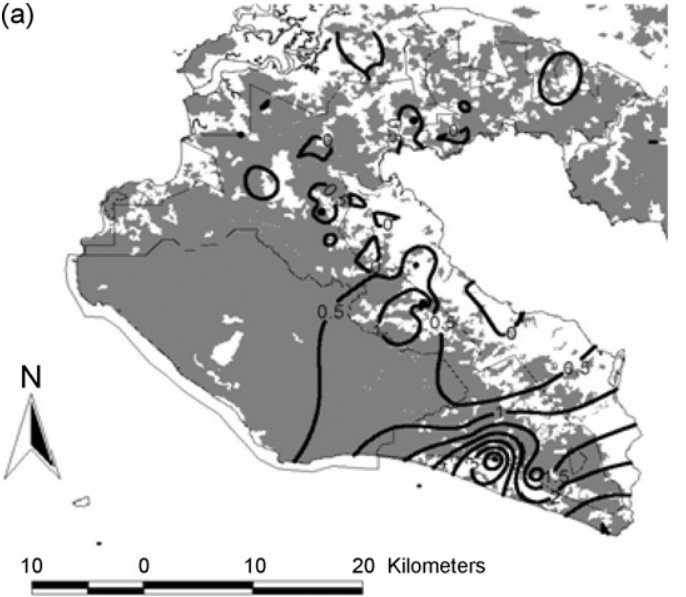

(b)

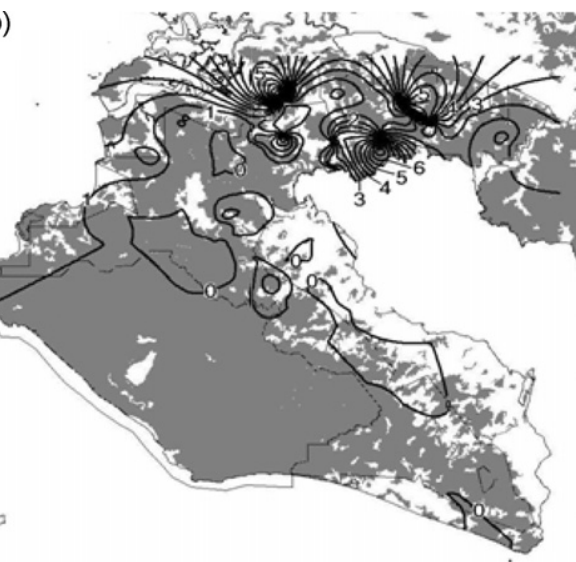

Fig. 2. Density curves of C. costaricense (a) and P. purpurea (b) in the Forestry Reserve of Golfo Dulce extrapolated from the density data points used in Fig. 1. Numbers over the lines represent the number of individuals/hectare of $>50 \mathrm{~cm}$ dbh.

Park that were previously monitored for demographic data, were geo-positioned using a Garmin 76 GPS. With the regional tree densities and the geographic coordinates we generated a database that was used to estimate the density of each tree species throughout Osa Peninsula using the kriging interpolation method $\left(\right.$ Surfer $^{\circledR}$, Golden Software, Inc. 2002). This analysis generates a raster map with tree density curves that increase by 0.5 individual ha ${ }^{-1}$ units. ANOVA was used to evaluate the fit of interpolated data with the observed densities. Density maps of $P$. purpurea and $C$. costaricense were overlaid on forest cover maps (Fig. 2a and b) to compare the local tree species density against the forest area, allowing estimation of local abundance of each species.

\subsection{Selective logging and tree abundance}

During June 2002 we conducted a census on seedlings and juveniles of $C$. costaricense and $P$. purpurea on 11 of the 94 farms with forest management plans used on the previous section. The census was used to determine the effects of selective logging on the abundance and demographic structure of these size categories. The forest area inside these farms was logged in 1997-1998; therefore the census was conducted 4-5 years after logging was conducted. We established six 100$\mathrm{m} \times 30$-m plots within each farm, three in absolute-protection areas and three in managed areas. Plots in selectively logged forests were set at the edge of timber loading areas, avoiding sides of skidding or extraction roads. Plots in absoluteprotection areas were set randomly inside the mature forest area, separated from each other by at least $100 \mathrm{~m}$. Individuals from $P$. purpurea and $C$. costaricense were classified by size as seedlings ( $<50 \mathrm{~cm}$ tall), small juveniles $(>50 \mathrm{~cm}$ high, $<2 \mathrm{~cm}$ $\mathrm{dbh})$ and large juveniles $(2 \mathrm{~cm}>\mathrm{dbh}>10 \mathrm{~cm})$. All small and large juveniles of $P$. purpurea and $C$. costaricense, as well as seedlings of $C$. costaricense inside each plot, were mapped, tagged, and measured for height (to tallest meristem) and diameter (dbh or above ground). Seedlings from $P$. purpurea were counted on a $10-\mathrm{m}$ wide transect placed in the middle of the $100-\mathrm{m} \times 30-\mathrm{m}$ plot. The abundance of seedlings, small juveniles, and large juveniles were compared between managed and protected areas to determine the effect of selective logging on these stages. The abundance of each size category in logged and unlogged plots was compared by a generalized linear model, with the number of individuals per transect as the dependent variable, and logging category as main effect. A Poisson distribution of residuals and a log-link function was used in the analysis. Significance of managed category effect was determined by a Type I Likelihood Ratio Test (Stokes et al., 2000), which follows a Chi-square distribution with one degree of freedom. To present local seedling and juvenile densities in logged and unlogged plots, we classified the plots as high and low-density areas (Table 2). For $C$. costaricense, high-density plots were those located in the Southern area of Osa Peninsula. For $P$. purpurea, high-density plots were those located in the Northern area of Osa Peninsula.

\subsection{Demography}

Short-term effects of selective logging on population dynamics of $P$. purpurea in Osa Peninsula were studied in logged plots located in the high-density area of this species (Mogos, Northern Osa Peninsula). The plots were established by the Instituto Tecnologico de Costa Rica (ITCR) in 1990. In Mogos, the ITCR plots are four 1.0-ha plots where all timber species $>10 \mathrm{~cm}$ dbh are tagged and mapped and their fate and dbh have been determined every 2 years for the last 15 years. The plots were logged in January 1992, when approximately 56 trees ha ${ }^{-1}$ from 10 timber species were cut using different methods for the extraction (bulldozer, ox carts or both). Thirty percent of $P$. purpurea trees $>50 \mathrm{~cm}$ dbh were extracted. This logging intensity is lower than the currently practiced in official forestry management plans. Therefore, it is expected that the regeneration capacity showed by this species under logging practices, with extractions of $50 \%$ of the largest individuals, will be less than the regeneration rate observed in the ITCR plots. For $P$. purpurea trees, measurements after logging were made on 54 trees $10-50 \mathrm{~cm}$ dbh and 24 trees $>50 \mathrm{~cm} \mathrm{dbh}$. Trees with $<30 \mathrm{~cm}$ dbh were measured since 1992 . 
Mortality rates and diameter growing rates was calculated for size classes $10-30 \mathrm{~cm} \mathrm{dbh}, 30-50 \mathrm{~cm}$ dbh and $>50 \mathrm{~cm} \mathrm{dbh}$. Annual mortality rates $(M)$ for each class was estimated as:

$M=\frac{\ln N_{0}-\ln N_{15}}{15}$

where $N_{0}$ is the number of individuals for each diameter class in 1990 , and $N_{15}$ is the number of individuals alive 15 years after 2005 , corresponding to a cutting cycle lapse. Sample in $N_{0}$ does not include the trees cut during 1992.

\section{Results}

\subsection{Analysis of distribution and local density}

Fig. 2a shows the estimated density curves for $C$. costaricense. This map shows that the highest densities of this tree species occurred in the southern part of Osa Peninsula. An analysis of variance indicates that the extrapolation used to create the maps explained $26 \%$ of the observed variation in adult densities, and the proportion of the explained variation is highly significant $\left(F_{2,89}=15.474, p<0.01, R^{2}=0.258\right)$.

The density curves calculated for $P$. purpurea are shown in Fig. 2b. In contrast to $C$. costaricense, $P$. purpurea is mainly distributed in the northern part of the peninsula, with an eastwest density gradient. The highest densities are near the Mogos region and to the northwest of this site. The populations of this species are restricted to areas with slopes greater than $30 \%$. The density curves explained $30 \%$ of the variation of the observed densities and the model is highly significant $\left(F_{2,89}=18.27\right.$, $\left.p<0.01, R^{2}=0.290\right)$.

The density curves show that, for both species, the sites with the highest densities have experienced a considerable reduction in their original forest cover (Fig. 2a and b). This suggests that a large proportion of populations with high densities of $C$. costaricense and $P$. purpurea have been lost with deforestation. In these areas of high density, floristic surveys conducted by foresters on the hilltops - areas with remaining forest cover - show that the original abundance of both species was large $\left(>5\right.$ individuals $\left.\mathrm{ha}^{-1}\right)$. Nonetheless, these areas have experienced severe deforestation, reaching $50 \%$ of the original forested coverage. It is important to notice that the highest density areas of both species are not included in the Corcovado National Park, located in the SW side of the Osa Peninsula. The most unprotected populations are those of $P$. purpurea; this species has a low density where the National Park is located. The patterns of distribution of species densities within specific subregions inside the Osa Peninsula inferred from the density curves match the observed plant inventories that had been conducted in this area (Quesada et al., 1997.

\subsection{Logging effects on seedlings and juveniles abundance}

The abundance of seedlings of $C$. costaricense was higher in unlogged than in logged plots (Table $2, X^{2}=8.92, p<0.01$ ). The number of small juveniles was also significantly greater in
Table 1

Annual mortality and growth rates for $P$. purpurea, based on observations performed in the Instituto Tecnológico de Costa Rica permanent plots for the years 1990-2005

\begin{tabular}{llllll}
\hline Stage & $\begin{array}{l}\text { No. of } \\
\text { trees }\end{array}$ & $\begin{array}{l}\text { Annual mortality } \\
\text { rate }(\%)\end{array}$ & $\begin{array}{l}\text { Diameter growth } \\
\left(\mathrm{mm} \mathrm{year}^{-1}\right)\end{array}$ & \\
\cline { 3 - 5 } & & & Median & Minimum & Maximum \\
\hline $10-30 \mathrm{dbh}$ & 28 & 1.5 & 3.58 & 0.0 & 12.4 \\
$30-50 \mathrm{dbh}$ & 11 & 0.0 & 7.19 & 0.4 & 10.5 \\
$>50 \mathrm{dbh}$ & 23 & 1.0 & 0.83 & 0.0 & 6.1 \\
\hline
\end{tabular}

unlogged plots (Table 2, $X^{2}=5.56, p<0.05$ ). Nonetheless, the number of juveniles between 2 and $10 \mathrm{~cm}$ dbh are more frequent in logged plots than in unlogged plots (Table 2, $\left.X^{2}=4.19, p<0.05\right)$.

In the case of $P$. purpurea, the number of seedlings is also significantly greater in unlogged than in logged plots (Table 2, $\left.X^{2}=176.4, p<0.01\right)$. However, the number of small and large juveniles was not significantly different between unlogged and logged plots (Table 2, $X^{2}=0.93, p>0.05, X^{2}=0.15, p>0.05$, for small and large juveniles data, respectively).

\subsection{Demography}

Table 1 shows mortality rates and diameter growing rates for $P$. purpurea trees within the logged plots. Mortality rates in the sample of $P$. purpurea trees do not differ between lower and higher diameter classes $\left(X^{2}=2.76\right.$, d.f. $=2$, $p>0.05)$. Fig. 3 shows the number of trees in four diameter classes during a 15-year interval before and after logging in 1992. After a drastic reduction in the number of trees $>80 \mathrm{~cm}$ dbh after logging, the number of trees in this size class, as well as the number of trees in the 50-80 and 30$50 \mathrm{~cm}$ dbh size classes, have experienced only small changes. However, the $10-30 \mathrm{~cm}$ dbh size class shows a reduction after logging, changing from 30 to 25 trees in the 4-ha plot in 15 years (Fig. 3 )

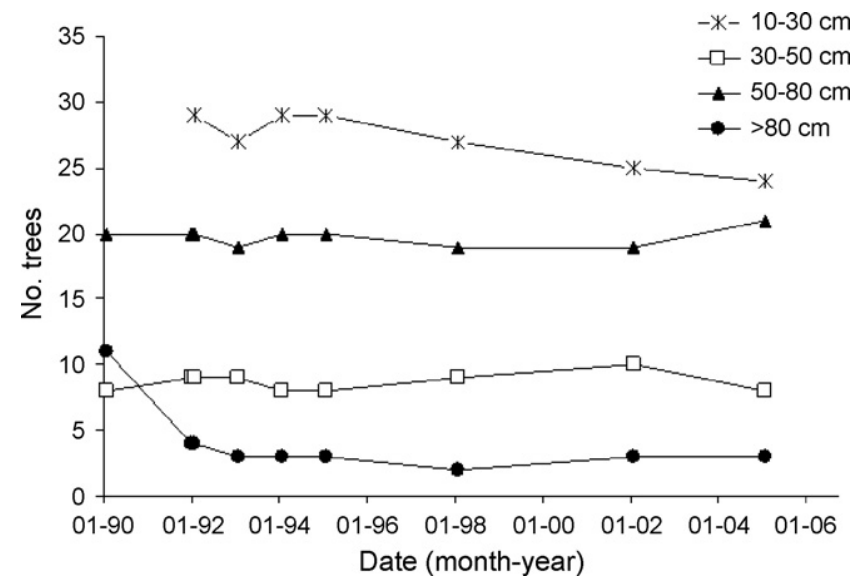

Fig. 3. Number of individuals of $P$. purpurea in different diameter classes in a 4-ha plot in Mogos, Osa Peninsula. Logging occurred a month before the 01-92 density measure. 
Table 2

Number of individuals per hectare of seedlings (height $<50 \mathrm{~cm}$ ), small juveniles ( $>50 \mathrm{~cm} \mathrm{dbh,}<2 \mathrm{~cm} \mathrm{dbh),} \mathrm{and} \mathrm{large} \mathrm{juveniles} \mathrm{(} 2-10 \mathrm{~cm}$ dbh) of $P$. purpurea and $C$. costaricense in logged and unlogged transects in the Osa Peninsula, Costa Rica

\begin{tabular}{|c|c|c|c|c|c|}
\hline \multirow[t]{2}{*}{ Species } & \multirow[t]{2}{*}{ Local density } & \multirow[t]{2}{*}{ Management category } & \multicolumn{3}{|c|}{ Size category } \\
\hline & & & Seedlings & $<2 \mathrm{~cm} \mathrm{dbh}$ & $2-10 \mathrm{~cm} \mathrm{dbh}$ \\
\hline \multirow[t]{4}{*}{ C. costaricense } & \multirow[t]{2}{*}{ High } & Unlogged & 4.5 & 8.0 & 2.4 \\
\hline & & Logged & 3.1 & 5.2 & 4.3 \\
\hline & \multirow[t]{2}{*}{ Low } & Unlogged & 3.9 & 2.7 & 0.2 \\
\hline & & Logged & 0.3 & 1.1 & 1.0 \\
\hline \multirow[t]{4}{*}{$P$. purpurea } & \multirow[t]{2}{*}{ High } & Unlogged & 511.2 & 3.1 & 2.2 \\
\hline & & Logged & 208.8 & 2.2 & 2.6 \\
\hline & \multirow[t]{2}{*}{ Low } & Unlogged & 0.8 & 0.4 & 0.3 \\
\hline & & Logged & 0.0 & 0.2 & 0.3 \\
\hline
\end{tabular}

Observations are classified in high or low local density classes for each species.

\section{Discussion}

The most important remnant populations of $C$. costaricense and $P$. purpurea throughout their distribution are located in Peninsula de Osa, Costa Rica (Jiménez, 1993, 1999). Our results indicate that the areas of greater density of these species within the Osa Peninsula have lost $50 \%$ of forest cover and occur in forest fragments. Based on the analysis of 94 forestry management plans in Osa, selective logging of these species has concentrated in these areas (Fig. 1). Extrapolation of the density curves of both species to actual deforested areas showed that most of the original populations have disappeared as a consequence of the high deforestation rates that have affected the Golfo Dulce Forestry Reserve in the last 20 years. Therefore, the exploitation of $C$. costaricense and $P$. purpurea is taking place in the last reservoirs of seed and genetic diversity sources of these species. These reservoirs are located outside the Corcovado National Park, where absolute protection would be guaranteed.

Our results indicated that selective logging negatively affects the abundance of seedlings of $C$. costaricense and $P$. purpurea in areas subject to forest management and the effect is still noticeable 4-5 years after logging was conducted. Three possible explanations, which are not mutually exclusive, can be given for these results. First, mechanical damage caused by the logging practices may have reduced the number of seedlings and small sapling populations. Many seedlings and juveniles in managed plots may be damaged by logging operations (skidder trails, tree fall, etc.), including plants in areas outside of logging roads. Soil compaction and the removal of top soil have been shown to occur during mechanized logging (Uhl and Guimarães-Vieira, 1989; Fredericksen and Pariona, 2002). However, good germination and growing of several commercial tree species in skidder trails have been reported (Fredericksen and Pariona, 2002). Second, logging gaps can promote the establishment of pioneer tree species, lianas, shrubs and herbs, which can affect the regeneration of commercial tree seedlings, especially shade-tolerant species (Costa et al., 2002; Pariona et al., 2003). Third, the extraction of the largest reproductive trees may reduce the number of seeds recruited into the seed bank with a subsequent reduction in the cohort of seedlings. Although evaluations of logging effects on fruit production and seed rain of timber species are scarce in the literature, there is evidence that logging practices can reduce over time the incorporation of seeds and recruitment of seedlings from extracted species. Chapman and Chapman (1997) reported that the number of fruits of most timber species decreased in logged areas in Uganda. Curran et al. (1999) showed a significant reduction in seed production and seedling regeneration after logging in a Dipterocarp tropical forest in Borneo. Grogan and Galvão (2006) report that fruit production in Swietennia macrophylla depended on a few individuals of the largest diameter categories on certain years; this in turn, made the regeneration after logging very limited. In Quercus costarricensis, Guariguata and Sáenz (2001) showed for a mast-fruiting year that acorn production within logged plots was higher than in adjacent, unlogged plots, but acorn germination and seedling establishment did not vary among plot types.

In contrast to the comparisons of seedling densities between logged and unlogged plots, individuals between 2 and $10 \mathrm{~cm}$ $\mathrm{dbh}$ of $C$. costaricense are significantly more frequent in managed than protected areas, but these trees became established before logging occurred. Higher growth rates of juveniles, caused by the extraction of adult trees and consequent opening of the canopy, can explain this result (Saenz and Guariguata, 2001). In the case of $C$. costaricense and $P$. purpurea on the Osa Peninsula, it can be concluded that different forces affecting survival and growth of timber tree seedlings and juveniles in logged habitats have resulted in the reduction of the densities of these size classes. The detection of this trend might be favored by the experimental design used in this study, where control plots were established in areas adjacent to logged plots, in a pair wise design. In other studies, control plots are located in a limited area frequently distant to logged plots, increasing the effect of environmental heterogeneity in the error term of the model (Bennett and Adams, 2004).

Growth rates of $P$. purpurea are within the range observed for slow growing, shade-tolerant tropical trees in diameter classes $>50 \mathrm{~cm}$ dbh (Clark and Clark, 1992). Estimates of mortality rates for this species are compatible with those from forestry plots for trees of higher diameter classes (Condit et al., 1995). In our experimental plot, 15 years after logging of $30 \%$ of the adult trees, the population of $P$. purpurea is far from 
recovering of the density levels before logging. The growth of intermediate size classes $\left(\sim 7.19 \mathrm{~mm}\right.$ year ${ }^{-1}$ for trees $30-50 \mathrm{~cm}$ $\mathrm{dbh}$ ) predict that trees in this class diameter will spend 28 years in this diameter class. Assuming a uniform distribution of individuals in this size class (11 trees in the plot), recruitment of trees to harvesting size classes can be just one tree every 2.6 years, after correction for natural mortality (Caswell, 2001). For the 15 years of data in the experimental plots (ITCR plots), six individuals passed from $30-50 \mathrm{~cm}$ to $>50 \mathrm{~cm}$ dbh size class, but during the same period five individuals from class $>50 \mathrm{~cm}$ dbh died from natural causes. This result is expected with a $1.5 \%$ mortality rate. Recruitment from class $50-80$ to $>80 \mathrm{~cm}$ dbh was zero in the same period.

These numbers can explain why the number of individuals $>80 \mathrm{~cm} \mathrm{dbh}$ (the harvested class) within the plot have decreased from four individuals immediately after logging to three individuals in the present, whereas individuals within the diameter class $50-80 \mathrm{~cm}$ dbh have remained almost constant since then. In this plot, recurrent 15-year cutting cycles of $50 \%$ of adult trees, as it is practiced by conventional logging in Costa Rica, may lead to the extinction of older and biggest size classes that include the main reproductive individuals in these populations. The impact of this reduction in seedling and juvenile categories is uncertain, although the observed reduction in the number of individuals in the $10-30 \mathrm{~cm} \mathrm{dbh}$ within the experimental plot can be a consequence of recruitment limited by seed production, as observed in the comparisons of seedling number of this species in logged and unlogged plots. These conclusions are in agreement with experimental plot observations and predictions of demographic models that studied long-term effects of logging on populations of other tropical timber trees (Gourlet-Fleury et al., 2005). In experimental plots in Guyana, higher size classes of Dicorynia guianensis have recovered only $50 \%$ of their initial stock after 15 years of logging. Demographic models showed that extraction of all adults $>60 \mathrm{~cm}$ dbh each 40 years is not sustainable over the long term (Gourlet-Fleury et al., 2005).

Selective logging practices in Costa Rica have been supported by environmental service payments, under the assumption that these practices help maintain the sustainable use of tropical forest resources. Our results demonstrate that selective logging practices used in the Osa Peninsula have a negative impact on the demographic structure of two important timber species, and increase the extinction probability of managed populations. Other tropical timber tree species with similar biogeographic, reproductive and demographic patterns may be suffering the same consequences from selective logging. The proportion of plant species that are endemic to specific countries has been estimated to be $46-62 \%$ of the global flora (Pitman and Jørgensen, 2002). Most plant endemism is concentrated in tropical biodiversity hotspots (Pitman and Jørgensen, 2002), such as Mesoamerica and northeastern South America.

Many tropical timber species are characterized by low diameter growth rates. In a sample of 93 Amazonian tree species $>10 \mathrm{~cm} \mathrm{dbh}$, the $50 \%$ quartile of annual diameter growth was $1.1 \mathrm{~mm}$ year $^{-1}$ (Laurance et al., 2004), and growth was correlated with species wood density. Therefore, many timber tree species are expected to show slow regeneration rates after selective extraction of reproductive trees, as it was observed in $P$. purpurea, a hardwood timber tree. More studies are necessary to establish ecologically sound policies of selective logging that are species-specific.

\section{Acknowledgments}

We thank Gumersindo Sanchez, Alberto Valencia G. and Heberto Ferreira M. for logistical support and Guido Saborío, Víctor Julio Guzmán, Mauricio Fernández and Eduardo Chacón for assistance in field work. This work was supported partially by grants from the Programa Conjunto INBio-SINAC (Programa Integrado Desarrollo de Recursos de Biodiversidad, World Bank), Vicerrectoría de Investigación de la Universidad de Costa Rica (Programa Institucional Osa-Golfo Dulce) and the Consejo Nacional de Investigación y Tecnología de México (CONACYT) to M.Q. and J:A:L. (U50863Q).

\section{References}

Americas Regional Workshop (Conservation \& Sustainable Management of Trees, Costa Rica), 1998. Caryocar costaricense. In: IUCN 2006. 2006 IUCN Red List of Threatened Species. www.iucnredlist.org.

Asner, G.P., Knapp, D.E., Broadbent, E.N., Oliveira, P.J.C., Keller, M., Silva, J.N., 2005. Selective logging in the Brazilian Amazon. Science 310, 480 482.

Barrantes, G., Jiménez, Q., Lobo, J.A., Maldonado, T., Quesada, M., Quesada, R., 1999. Evaluación de los planes de manejo forestal autorizados en el período 1997-1999 en la Península de Osa. Cumplimiento de normas técnicas, ambientales e impacto sobre el bosque natural. Informe para Fundación Cecropia.

Bawa, K.S., Seidler, R., 1998. Natural forest management and conservation of biodiversity in tropical forests. Cons. Biol. 12, 46-55.

Bennett, L.T., Adams, M.A., 2004. Assessment of ecological effects due to forest harvesting: approaches and statistical issues. J. Appl. Ecol. 41, 585-598.

Cannon, C.H., Peart, D.R., Leighton, M., 1998. Tree species diversity in commercially logged Bornean rainforest. Science 281, 1366-1368.

Caswell, H., 2001. Matrix Population Models. Sinauer Associates, Inc.

Chapman, C., Chapman, L.J., 1997. Forest regeneration in logged and unlogged forests of Kibale National Park, Uganda. Biotropica 29, 396-412.

Clark, D.A., Clark, D.B., 1992. Life history diversity of canopy and emergent trees in a Neotropical rain forest. Ecol. Monogr. 62, 315-344.

Claudine, S., Vartanián, D., Polimeni, J., 2003. Caracterización Social, Económica y Ambiental del Área de Conservación Osa. Dirección de Sociedad Civil, Ministerio del Ambiente y Energía, San José, Costa Rica.

Condit, R., Hubbell, S.P., Foster, R., 1995. Mortality rates of 205 Neotropical tree and shrub species and the impact of a severe drought. Ecol. Monogr. 65 419-439.

Costa, F.R.C., Magnusson, W.E., 2003. Effects of selective logging on the diversity and abundance of flowering and fruiting understory plants in Central Amazonian forest. Biotropica 35, 103-114.

Costa, F.R.C., Senna, C., Nakkazono, E.M., 2002. Effects of selective logging on populations of two tropical understory herbs in an Amazonian forest. Biotropica 34, 289-296.

Curran, L.M., Caniago, I., Paoli, G.D., Astianti, D., Kusneti, M., Leighton, M., Nirarita, C.E., Haeruman, H., 1999. Impact of El Niño and logging on canopy tree recruitment in Borneo. Science 286, 2184-2188.

Dauber, E., Fredericksen, T.S., Peña, M., 2005. Sustainability of timber harvesting in Bolivian tropical forests. For. Ecol. Manage. 214, 294-304. 
Fredericksen, T.S., Pariona, W., 2002. Effect of skidder disturbance on commercial tree regeneration in logging gaps in a Bolivian tropical forest. For. Ecol. Manage. 171, 223-230.

Gourlet-Fleury, S., Cornu, G., Jésel, S., Dessard, H., Jourget, J., Blanc, L., Picard, N., 2005. Using models to predict recovery and assess tree species vulnerability in logged tropical forests: a case study from French Guiana. For. Ecol. Manage. 209, 69-86.

Grogan, J., Galvão, J., 2006. Factors limiting post-logging seedling regeneration by big-leaf mahogany (Swietenia macrophylla) in Southeastern Amazonia, Brazil, and implications for sustainable management. Biotropica 38, 219-228.

Guariguata, M., Sáenz, G., 2001. Post-logging acorn production and oak regeneration in a tropical montane forest, Costa Rica. For. Ecol. Manage. 167, 285-293.

Jiménez, Q., 1993. Arboles maderables en peligro de extinción en Costa Rica. Museo Nacional de Costa Rica, San José, Costa Rica.

Jiménez, Q., 1999. Arboles maderables en peligro de extinción en Costa Rica, vol. II actualizado y ampliado. Instituto Nacional de Biodiversidad, San José, Costa Rica.

Laurance, W.F., Nascimento, H.E.M., Laurance, S.G., Condit, R., D’Angelo, S., Andrade, A., 2004. Inferred longevity of Amazonian rainforest trees based on a long-term demographic study. For. Ecol. Manage. 190, 131-143.

Maldonado, T., 1998. Uso de la Tierra y Fragmentación de bosques: Algunas Areas Críticas en el Area de Conservación Osa. In: Rosero, L. (Ed.), Conservación del Bosque en Costa Rica. Academia Nacional de Ciencias. Programa Centroamericano de Población, San José, Costa Rica, pp. 2849.

Nepstad, D.C., Veríssimo, A., Alentar, A., Nobre, C., Lima, E., Lefebvre, P., Schlesinger, P., Potter, C., Moutinho, P., Mendoza, E., Cochrane, M., Brooks, V., 1999. Large scale impoverishment of Amazonian forests by logging and fire. Nature 398, 505-508.
Pariona, W., Fredericksen, T.S., Licona, J.C., 2003. Natural regeneration and liberation of timber species in logging gaps in two Bolivian tropical forests. For. Ecol. Manage. 181, 313-322.

Pitman, N.C.A., Jørgensen, P.M., 2002. Estimating the size of the world's threatened flora. Science 298, 989.

Prance, G.T., 1976. Caryocaraceae. Flora of Panama. In: Woodson, R.E., Shery, R.W. (Eds.), Ann. Missouri Bot. Garden 63 (3 Pt 6), 541-546.

Quesada, F.J., Jiménez, Q., Zamora, N., Aguilar, R., Gonzáles, J., 1997. Arboles de la Península de Osa. INBio, 1 ed. Heredia, Costa Rica.

Quesada, M., Stoner, K.E., 2004. Threats to the conservation of tropical dry forest in Costa Rica. In: Frankie, G.W., Mata, A., Vinson, S.B. (Eds.), Biodiversity Conservation in Costa Rica: Learning the Lessons in a Seasonal Dry Forest. University of California Press, Berkeley, California, pp. 266-280.

Rosero-Bixby, L., Maldonado-Ulloa, T., Bonilla-Carrión, R., 2002. Bosque y población en la Península de Osa, Costa Rica. Rev. Biol. Trop. 50, 585-598.

Saenz, G.P., Guariguata, M.R., 2001. Demographic response of tree juveniles to reduced-impact logging in a Costa Rican montane forest. For. Ecol. Manage. 140, 75-84.

Stokes, M.E., Davis, C.S., Koch, G.G., 2000. Categorical Data Analysis Using the SAS System, 2nd ed. SAS Institute, Cary, North Carolina, USA.

Uhl, C., Guimarães-Vieira, I.C., 1989. Ecological impacts of selective logging in the Brazilian Amazon: a case study from the Paragominas Region of the State of Pará. Biotropica 21, 98-106.

Weissenhofer, A., Huber, W., 2001. Basic geographical and climatic features of the Golfo Dulce Region. In: Weber, A. (Ed.), An Introductory Field Guide to the Flowering Plants of the Golfo Dulce Rainforests, Costa Rica. Biologiezentrum des Oberösterreichischen Landesmuseums, Linz, pp. $11-14$.

World Resources Institute, 1985. Tropical Forests: a call for action. Report on an International Task Force convened by the World Resources Institute, The World Bank, and the United Nations Development Programme, New York. 